\title{
Use, Production and Existence of Local Artemia Resources in Uganda and Africa: A Review
}

\author{
Mujibu Nkambo* \\ Aquaculture Research and Development Center -Kajjansi, National Fisheries Resources Research Institute \\ (NaFIRRI) \\ P O box 530, Kampala, Uganda \\ Matthew Mwanja \\ Aquaculture Research and Development Center -Kajjansi, National Fisheries Resources Research Institute \\ (NaFIRRI) \\ P O box 530, Kampala, Uganda \\ John S Balirwa \\ National Fisheries Resources Research Institute (NaFIRRI) \\ P O box 343, Jinja, Uganda \\ Fredric W Bugenyi \\ Department of Biological Sciences, College of Natural Sciences (CONAS), \\ Makerere University, Kampala, P. O. Box 7260, Uganda
}

\begin{abstract}
The research was funded by National Agricultural Research Organisation (NARO) of Uganda.
\section{Abstract}

This study was aimed at reporting the existing Artemia habitats, its use and production in Uganda and Africa as a continent. In light of the great importance of Artemia as a starter feed in the aquaculture industry, its current shortage in supply, the need for commercial exploitation of local Artemia resources and development of new Artemia resources. Over 50 peer reviewed journal articles were reviewed to provide an understanding of the current status of Artemia use, production and existence of local existing Artemia resources in Uganda and Africa as continent. The study revealed neither local occurring Artemia resources nor commercial Artemia production is currently existent in Uganda, with its use mainly restricted to a few existing commercial hatcheries. Generally Artemia use in Africa is mainly restricted to the few commercial fish hatcheries. Literatures points to North African countries boarding the Mediterranean to be leading in the number of Artemia sites and production in Africa.
\end{abstract}

Keywords: Artemia habitats, Hypersaline lakes, Aquaculture

DOI: $10.7176 /$ JNSR/9-18-04

Publication date:September $30^{\text {th }} 2019$

\section{Introduction}

Artemia are typical inhabitants of hypersaline environments belonging to anostracan micro-crustaceans of genus Artemia (Gajardo, Parraguéz et al. 2001 ; Kaiser, Gordon et al. 2006; Ogello, Kembenya et al. 2014). Although Schlosser is reported by scientific manuscripts to have the first description of Artemia in saltpans of Lymington, Hampshire (England) in 1755 (Kuenen. and Becking. 1938; Asem. 2008), Artemia records in lake Urmia dates back to 982 by unknown Iranian author (Asem. 2008; Ben Naceur, Jenhani et al. 2012; Kara and Amarouayache 2012). Mankind has known Artemia for so many years with native Amerindian and Lybians reported to have been using Artemia as food so many years ago (Asem. 2008). Artemia is a primitive arthropod having a segmented body, with leaf-like appendages known as thoracopodes. Adult Artemia is reported to vary in length between 8 to $10 \mathrm{~mm}$ and 10 to $12 \mathrm{mms}$ for males and females respectively. Both males and females are reported to have an approximate width of about $4 \mathrm{~mm}$ (FAO 2015). This genus is reported to have bisexual and parthenogenetic populations that are similar morphologically and biometrically (Triantaphyllidis, Abatzopoulos et al. 1998; Nasser, Peter et al. 2009; MUÑOZ and PACIOS 2010; Castro-Mejía, Castro-Barrera et al. 2011). Bisexual Artemia populations include Artemia franciscana and Artemia persimilis which have been classified as the new world Artemia populations and are usually diploids while their parthenogenetic relatives (A. salina, A. sinica, A. urmiana and A. tibetiana) which are polyploids are referred to as the Old World populations (Triantaphyllidis, Criel et al. 1997; Baxevanis, Kappas et al. 2006; Maccari, Amat et al. 2013). Bisexual populations are found on all continents except the Antarctica while parthenogenetic populations are endemic to Europe, Asia and Australia (Triantaphyllidis, Criel et al. 1997). Reproduction in Artemia is reported to be by either ovoviviparity where eggs hatch into live young ones within the body before being released or oviparity where metabolism and embryonic development in the embryo are arrested to form diapausing cysts (Nasser, Peter et al. 2009; Sugumar 2010). The later has been reported as a crucial strategy for surviving unfavorable environment conditions, where the cysts remain in this stage of arrested 
metabolism and remain viable for many years (Papeschi., Alba et al. 2008). Different conditions have been reported to be responsible for the switch between Ovoviviparity and oviparity.

Artemia has been reported to have a wide geographical distribution (Kaiser, Gordon et al. 2006; Ben Naceur, Jenhani et al. 2009), occurring in all continents with the exception of the Antarctica (Papeschi., Alba et al. 2008; Ben Naceur, Jenhani et al. 2009; Ben Naceur, Jenhani et al. 2012). Over 600 habitats of Artemia populations have been reported world-wide in natural salt water bodies and man-made salterns (Ogello, Kembenya et al. 2014; Van Stappen 2002 ). The distribution of these populations are reportedly reflected in paths of some migratory birds as well as intentional inoculations by man for commercial purposes (Nasser, Peter et al. 2009; Munoz, Green et al. 2013). It is adapted to survive and live under hypersaline conditions in salt lakes, ponds, coastal salt lagoons, pans and solar saltworks (Kaiser, Gordon et al. 2006; Ben Naceur, Jenhani et al. 2009; Ogello, Kembenya et al. 2014). They have been reportedly found in athalassohaline and thalassohaline environments with salinities as high as 340g/l (Nasser, Peter et al. 2009; Ogello, Kembenya et al. 2014). Artemia is reported to withstand stressful conditions imposed by hypersaline environments such as fluctuating temperatures, salinity, and ionic composition (Gajardo and Beardmore 2012; Ogello, Kembenya et al. 2014). Being highly osmotolerant (Ogello, Kembenya et al. 2014) and the ability to have an interchangeable life cycle which can switch between diapausing cysts and live nauplii depending on environmental conditions are some of the key adaptations reported to enable Artemia to withstand these stressful conditions (Kaiser, Gordon et al. 2006; Ben Naceur, Jenhani et al. 2009; Gajardo and Beardmore 2012). A number of literatures have pointed to salinity as the main environmental parameters affecting the distribution of Artemia (Vanhaecke, Tackaert et al. 1987; Kaiser, Gordon et al. 2006), with other like temperature, light intensity, food availability more responsible for the numbers and densities of Artemia populations (Vanhaecke, Tackaert et al. 1987).

Artemia is reported to be among the most widely used live feed for larviculture of fish and shell fish (Sorgeloos, Lavens et al. 1991; Philips 2010), with over 2000 metric tons of dry Artemia cysts produced and marketed annually world-wide (FAO 1996; Triantaphyllidis, Abatzopoulos et al. 1996; Ogello, Kembenya et al. 2014). Despite man having known Artemia for centuries, its use as food for larvae in the aquaculture industry began only in the 1930s when it was discovered to be nutritional rich for new hatched larvae (Bengtson, Leger et al. 1991; FAO 1996; Ogello, Kembenya et al. 2014). Since then Artemia was mainly collected from natural saline lakes and coastal salt works. As a result of the rapid expansion of the aquaculture production more especially in 1970's, the demand for Artemia exponentially increased to exceed production (FAO 1996; Sorgeloos, Dhert et al. 2001). Since then limited supply of Artemia has become a big impediment to the expansion of the aquaculture (Sorgeloos, Lavens et al. 1991; FAO 1996; Coutteau and Sorgeloos 1997; Maung, Nyi Bu et al. 2008), with many countries importing Artemia at prices ranging between US\$ 50 to 100 per kg (Jaccarini and Martens 1990; Bengtson, Leger et al. 1991). Annually Artemia production has been reported to fluctuate hence affecting Artemia market prices as well as raising hatchery production costs (Maung, Nyi Bu et al. 2008; Schwartz 2008).

Rotifers and Artemia are among the most used extensively used zooplanktons for larval rearing both in marine and freshwater aquaculture (Bengtson, Leger et al. 1991; Akbary, Hosseini et al. 2011; Ramesh, Dube et al. 2014). Availability as an off-the-shelf feed in form of dormant cysts is one of the key advantages of Artemia over other live feeds (Leger, Bengtson et al. 1987; Akbary, Hosseini et al. 2011). Artemia is hardy, ease to hatch (Tarekegn 2015), tolerant to unfavorable environmental changes, with a wide size range and different physical forms (Leger, Bengtson et al. 1987). Artemia if well packaged can stay viable for so many years (Bengtson, Leger et al. 1991; Ogello, Kembenya et al. 2014). All these render it more versatile and preferable in comparison to other live feeds. Other competitive advantages of Artemia use are the good nutritional value for fish larvae and the easy improvement in its nutritional value through enrichment techniques (Akbary, Hosseini et al. 2011). Through bioencapsulation Artemia has also be used as a route for transferring essential nutrients like Ascorbic acid (Immanuel, Citarasu et al. 2007; Akbary, Hosseini et al. 2011), probiotics (Arndt and Wagner 2007; Seenivasan, Bhavan et al. 2012), spawning hormone (Ogello, Kembenya et al. 2014), medication like anti-biotics (Nkambo, Bugenyi et al. 2015) and other feed supplements like Eicosapantaenoic acid (EPA) and decosahexanoic acid (DHA) to the fish (Han, Geurden et al. 2000). Ascorbic acids are necessary in the synthesis of collagen required in formation of connective tissue and bone matrix (Dabrowski and Blom 1994). Artemia production in salt ponds has also been documented to play a vital role in controlling algal blooms and thereby improving the salt crystallization process as well as leading to better salt quality (Ogello, Kembenya et al. 2014). Artemia is currently one of the model organisms which have been put to use in a number of environmental eco-toxicology, evolutionary and genetic studies (Baxevanis, Kappas et al. 2006; Ben Naceur, Jenhani et al. 2008; MUÑOZ and PACIOS 2010; Ogello, Kembenya et al. 2014).

Despite all the cited Artemia uses above and there being no single artificial diet that can be used as a completely substitute for Artemia in hatcheries (Ben Naceur, Jenhani et al. 2008) which makes it remain a must have feed in many hatcheries all over the world (Ogello, Kembenya et al. 2014), very little is known about its use, production and occurrence in Uganda and Africa as a continent. In this study potential Artemia sites in Uganda were visited and existing literature reviewed with an aim of investigating the existing information on the use, 
production and occurrence of Artemia in Uganda and Africa.

\section{Materials and Methods}

In this study over fifty (50) journal articles were reviewed for data and information about use, production and existence of local Artemia resources in Uganda and Africa.

\section{Discussion and Results}

From this is study, it was found out that literature highlighting the use of Artemia in Ugandan hatcheries and in African hatcheries at large is very scares. This could attribute to commercial hatcheries being very few in Uganda with the majority of them still dependant on un-standardised technologies and practices (Mwanja, Rutaisire et al. 2015). Uganda is reported to have only three commercial private hatcheries with the rest being small scale hatcheries. Only $31 \%$ of the Ugandan hatchery operators have been reported to use Artemia alone in weaning fish larvae (Mwanja, Rutaisire et al. 2015). This small percentage of farmers using Artemia could be attributed to high cost of imported Artemia (FAO 2011). No literature was found on the use of Artemia in the other East African countries. This could be attributed to the fact aquaculture is still mainly small scale as was reported in Tanzania (Chenyambuga, Mwandya et al. 2014). In Tanzania, Aquaculture was reported as subsistence activity for the poor households in some coastal and inland areas (Mallya 2007). At such small scale farmers common depend on the cheap green water cultures. Their fry production demands are not as high and therefore even with poor hatchery survival they can still have enough fingerlings for their subsistence production.

From the literature reviewed in this study, Nile tilapia (Oreochromis niloticus) and African catfish (Clarias gariepinus) were reported to be the leading aquaculture species in Africa with Egypt and Nigeria having the highest number of private commercial hatcheries, the majority of which were reported to be lacking an accreditation and certification systems and therefore unregulated (Brummett 2007). Uganda and other African countries like Cameroon, Ghana and Zimbabwe were reported to be mainly dependant on semi-commercial systems for seed production (Brummett 2007). This is in agreement with finding from Mwanja et al., (2015) where the majority of Ugandan hatcheries were reported to immediately wean fish larvae on natural feeds or a combination of natural feeds with dry feeds hence the low use of Artemia in Ugandan hatcheries. Many small hatcheries in Nigeria have been reported to wean and culture catfish larvae to fingerling in green water cultures (Adewumi and Olaleye 2011). Micro-algae and rotifers have been reported to be the main targeted feed from green water cultures. The choice of rotifers for weaning fish larvae was reported to have an advantage of low cost, with the difficulty to maintain pure cultures being the main disadvantage (Francis 2007). Commercial hatcheries being generally few, coupled with lack of regulation, accreditation, and certification systems in Africa; this makes information about hatchery practices to be very scares hence information on use of Artemia in African hatcheries also being scarce.

Much as Artemia populations have been well studied in other continents like America, Europe and Australia, reports documenting local Artemia resources in Africa are scarce with extremely little work done on characterisation of the known local Artemia resources (Triantaphyllidis, Abatzopoulos et al. 1996; Triantaphyllidis, Abatzopoulos et al. 1998). Although Artemia population have been reported to be found in natural salt lakes and man-made salterns in the tropical, sub-tropical and temperate climatic zones (FAO 1996), no literature documenting local Artemia resources in Uganda was found in this present study. Previous unpublished findings from a short study funded by the Belgian Development Cooperation (BTC) in 2010 where lakes Katwe, Bunyampaka, Kikorongo, Murumuri and Bagusa were surveyed, indicated that these lakes had no local Artemia resources but with huge potential for Artemia production (un-published). Other than the speculations made about the existence of Artemia cysts on the shores of salt lakes in Western Uganda (Ogello, Kembenya et al. 2014), there is no literature confirming the existence of local Artemia resources in Uganda. This could be attributed to the fact that with the exception of a 2 day exploratory visits done in 2008 by Prof. Patrick Sorgeloos of Artemia Reference Center (ARC), Gent University in Belgium and the short feasibility study which was funded by Belgian Development Co-operation (BTC) in 2010 there have been no efforts directed towards identifying Artemia resources in Uganda.

Due to favorable environment like the hypersaline lakes and salt lagoons, most African countries have been reported to have potential habitats for Artemia (Ogello, Kembenya et al. 2014) and therefore potential for it production. The majority of Artemia populations in Africa have reportedly been collected in countries with a coastline. Among the Mediterranean countries to have Artemia resources include Algeria, Egypt, Libya, Morocco (Kara and Amarouayache 2012) and Tunisia (Triantaphyllidis, Abatzopoulos et al. 1998; Ben Naceur, Jenhani et al. 2008). Other Africa countries where Artemia resources have been identified include Kenya (MUNOZ and PACIOS 2010), Madagascar, Mozambique, Namibia, Nigeria, Niger, Senegal, and South Africa (Triantaphyllidis, Abatzopoulos et al. 1998; Kaiser, Gordon et al. 2006). Most African Artemia habitats have been reported in countries boarding the Mediterranean region with Tunisia reported to have 23 sites (Ben Naceur, Jenhani et al. 2012), and this has been attributed to the high effort in the identification of Artemia resources in this region (Kaiser, Gordon et al. 2006). In 2010 Africa was reported to have a total of 92 Artemia localities, 57 of which are 
undescribed with unknown reproductive mode, 8 and 5 of which were undescribed parthenogenetic and sexual Artemia populations respectively (MUÑOZ and PACIOS 2010). The 92 localities in Africa compared to the 172 in Europe is a small number bearing in mind that Africa is several times big than Europe and with a more favorable climate. This difference points to the gap that needs to be filled by increasing research efforts toward identifying more Artemia resources in Africa.

Although very few studies have been directed towards reproductive characterization of Artemia strains in Africa, both parthenogenetic and sexually reproducing populations have been reported (Triantaphyllidis, Abatzopoulos et al. 1998; Kaiser, Gordon et al. 2006; MUÑOZ and PACIOS 2010). It is should be not that a good number of Artemia resources so far identified in these African countries are not local but were rather intentionally introduced or accidently introduced (MUÑOZ and PACIOS 2010), with some others being introduced by agents of Artemia dispersal like the migratory birds (Triantaphyllidis, Abatzopoulos et al. 1998; Munoz, Green et al. 2013). One of the well documented example is the Kenyan Artemia franciscana which was introduced between 1984 and 1986 in a collaborative project between Kenya Marine \& Fisheries Research Institute (KMFRI) and the Belgian Agency for Development Cooperation (BADC) with an aim of assessing the potential for Artemia production in the Kenyan coastal salt works (Radull, Rasowo et al. 1992; Mremi 2011; Ogello, Kembenya et al. 2014). Artemia franciscana is now reported to have spread along the Kenyan coast probably by agents of dispersals and has permanently established (Munguti, Kim et al. 2014; Ogello, Kembenya et al. 2014). Eight solar salt companies are reported to have Artemia inoculation policies with production in commercial and artisanal salt ponds already on-going (Ogello, Kembenya et al. 2014). More recently Artemia cysts genetically similar to Kenyan Artemia franciscana populations were reported at Tanga on the Tanzanian coast (Ogello, Kembenya et al. 2014). These might have been dispersed from the Kenyan coast but no literature pointing to Artemia production in Tanzania was found in this present study. Another example of intentional introductions are those of sexual Artemia franciscana used as live feed in aquaculture which was introduced in the Mediterranean basin and have been reported to be quickly replacing the native species (Amat, Hontoria et al. 2007; Kara and Amarouayache 2012). Since invasion success and impact depends on competiveness and trophic interaction in the environment having the native and invasive strain and are sometimes irreversible and hard to predict (Amat, Hontoria et al. 2007), from biodiversity conservation perspective it is important local Artemia resources are developed other encouraging introductions of invasive species. It is worth noting that none of the reviewed literature pointed to commercial Artemia production in Uganda, with very little hint on commercial Artemia production in Africa.

\section{Conclusions}

Much as the distribution of Artemia is well studied in many countries in other continents like Europe, America and Australia, very little is documented about Artemia, its use, production and distribution in Africa. Even among the identified local African Artemia resources, a big majority is not yet developed to allow for commercial exploitation. Despite the urgent need for affordable Artemia resources for use in Ugandan and African aquaculture no literature confirms the existence of Artemia resources in Uganda with records or Artemia use in Africa still very scanty. This situation justifies the pressing need more than ever for documentation of Artemia use, exploitation and development of African Artemia resources.

\section{Recommendations}

For sustainable Aquaculture development in Uganda and Africa as a continent, more efforts in form of research and development need to be directed towards identifying, establishing and development of local Artemia resources. This will allow for improved survival in Ugandan and African hatcheries hence addressing the current shortages in quality seed supply from the hatcheries cause by lack of a suitable live starter feed.

\section{Acknowledgement}

Special thanks and acknowledge is reserved for the National Agricultural Research Organisation (NARO), National Fisheries Resources Research Institute (NaFIRRI), Kajjansi Aquaculture Research and Development Center (KARDC), Department of Biological Science, Makerere University, and Entire consultancy team that carried out the first feasibility survey for Artemia occurrence in saline crater lakes in 2010.

\section{References}

Adewumi, A. A. and V. F. Olaleye (2011). "Catfish culture in Nigeria: Progress, prospects and problems." African Journal of Agricultural Research 6(6): 1281-1285.

Akbary, P., S. A. Hosseini, et al. (2011). "Enrichment of Artemia nauplii with essentail fatty acids and Vitamin C: effect on rainbow trout (Oncorhynchus mykiss) larvae performance." Iranian Journal of Fisheries Sciences 10(4): 557-569.

Amat, F., F. Hontoria, et al. (2007). "Biodiversity loss in the genus Artemia in the Western Mediterranean Region." Limnetica $26(2): 387-404$. 
Arndt, E. R. and J. E. Wagner (2007). "Enriched Artemia and Probiotic Diets Improve Survival of Colorado River Cutthroat Trout Larvae and Fry." North American Journal of Aquaculture 69(2): 190-196.

Asem., A. (2008). "Historical records on brine shrimp Artemia more than one thousand years ago from Urmia lake, Iran." Journal of Biological Research-Thessaloniki 9: 113 - 114.

Baxevanis, D. A., I. Kappas, et al. (2006). "Molecular phylogenetics and asexuality in the brine shrimp Artemia." Molecular Phylogenetics and Evolution 40(2006): 724-738.

Ben Naceur, H., A. B. R. Jenhani, et al. (2008). "Determination of biological characteristics of Artemia salina (Crustacea: Anostraca) population from Sabkhet Sijoumi (NE Tunisia)." Transitional Waters Bulletin 3: 6574.

Ben Naceur, H., A. B. R. Jenhani, et al. (2009). "Notes on Geographic Distribution: New distribution record of the brine shrimp Artemia(Crustacea, Branchiopoda, Anostraca) in Tunisia " CHeck list 5(2): 281-288.

Ben Naceur, H., A. B. R. Jenhani, et al. (2012). "Review of the biogeography of Artemia Leach, 1819 (Crustacea: Anostraca) in Tunisia." International Journal of Artemia Biology 2(1): 24 -39.

Bengtson, A. D., P. Leger, et al. (1991). Use of Artemia as food source for Aquaculture. Artemia Biology. R. A. Browne, S. Patrick and C. N. A. Troman. Boca Raton, FL, CRC Press.

Bengtson, A. D., P. Leger, et al. (1991). Use of Artemia as a food source for Aquaculture. Artemia Biology. R. A. Browne, P. Sorgeloos and C. N. A. Trotman. Boca Raton, FL, CRC Press.

Brummett, R. E. (2007). Freshwater fish seed supply: Africa regional synthesis, pp. 41-58. In: M.G. Bondad-Reantaso (ed.). Assessment of freshwater fish seed resources for sustainable aquaculture. . FAO Fisheries Technical Paper. Rome, FAO: 628.

Castro-Mejía, J., T. Castro-Barrera, et al. (2011). "Effects of salinity on growth and survival in five Artemia franciscana (Anostraca: Artemiidae) populations from Mexico Pacific Coast." Revista de Biología Tropical 59: 199-206.

Chenyambuga, S. W., A. Mwandya, et al. (2014). "Productivity and marketing of Nile tilapia (Oreochromis niloticus) cultured in ponds of small-scale farmers in Mvomero and Mbarali districts, Tanzania. . " Livestock Research for Rural Development. 26(43).

Coutteau, P. and P. Sorgeloos (1997). "Manipulation of dietary lipids, fatty acids and vitamins in zooplankton cultures." Freshwater Biology(38): 501-512.

Dabrowski, K. and J. H. Blom (1994). "Ascorbic acid deposition in rainbow trout, Oncorhynchus mykiss eggs and survival of embryos." Comparative Biochemistry and physiology 108A: 129-135.

FAO (1996). Manual on the production and use of live food for aquaculture. FAO Fisheries Technical Paper. L. Patrick and S. Patrick. Rome, FAO.

FAO (2011). "Cultured Aquatic Species Information Programme. Artemia spp.. Cultured Aquatic Species Information Programme. Text by Van Stappen, G. In: FAO Fisheries and Aquaculture Department (online). ." 2015, from http://www.fao.org/fishery/culturedspecies/Artemia_spp/en.

FAO (2015). "Aquaculture topics and activities. Aquaculture. ." FAO Fisheries and Aquaculture department (Online). $\quad$ Retrieved $19 \quad$ February, $\quad 2016, \quad$ from http://www.fao.org/fishery/culturedspecies/Artemia_spp/en.

Francis, A. (2007). "First Feeding in the African Catfish Clarias anguillaris Fry in Tanks with the Freshwater Rotifer Brachionus calyciflorus Cultured in a Continuous Feed Back Mechanism in Comparison with a Mixed Zooplankton Diet. ." Journal of Fisheries and Aquatic Science 2: 275-284.

Gajardo, G., M. Parraguéz, et al. (2001 ). "Reproduction in the brine shrimp Artemia: evolutionary relevance of laboratory cross-fertility tests. ." Journal of Zoology (253): 25-32

Gajardo, G. M. and J. A. Beardmore (2012). "The Brine Shrimp Artemia: Adapted to Critical Life Conditions." Frontiers in Physiology 3: 185.

Han, K., I. Geurden, et al. (2000). "Fatty acid changes in enriched and subsequently starved Artemia franciscana nauplii enriched with different essential fatty acids." Aquaculture 19(2001): 93-105.

Immanuel, G., T. Citarasu, et al. (2007). "Bioencapsulation strategy and highly unsaturated fatty acids (HUFA) enrichment in Artemia franciscana nauplii by using marine trash fish Odonus niger liver oil." African Journal of Biotechnology 6 (17): 2043-2053.

Jaccarini, V. and E. Martens (1990). The Ecology of Mangrove and Related Ecosystems: Proceedings of the International Symposium, Mombasa, Kenya.

Kaiser, H., A. K. Gordon, et al. (2006). "Review of the African distribution of the brine shrimp genus Artemia." Water SA 32(4): 597-604.

Kara, H. M. and M. Amarouayache (2012). "Review of the biogeography of Artemia Leach, 1819 (Crustacea: Anostraca) in Algeria " International Journal of Artemia Biology 2(1): 40-50.

Kuenen., D. J. and G. M. B. Becking. (1938). "Historical notes on Artemia Salina." Zoologischer Mededeelingen 20: 222 - 230.

Leger, P., A. D. Bengtson, et al. (1987). "The nutritional value of Artemia." Artemia Research and its Applications 
24: 521-623.

Maccari, M., F. Amat, et al. (2013). "Origin and Genetic Diversity of Diploid Parthenogenetic Artemia in Eurasia." PLOS ONE 2(8): 1 - 13.

Mallya, J. Y. (2007). THE EFFECTS OF DISSOLVED OXYGEN ON FISH GROWTH IN AQUACULTURE. Reykjavik, Iceland, The United Nations University. Fisheries Training Programme.

Maung, S. E. E., M. T. Nyi Bu, et al. (2008). Production of Artemia Cysts and Flakes Using Improved Techniques in Rock Salt Solution GMSARN International Conference on Sustainable Development: Issues and Prospects for the GMS.

Mremi, P. A. (2011). Pond production of Artemia in a solar salt work in Kenya. Faculty of Bio-Science Engineering. Gent, Gent University. Master of Aquaculture: 103.

Munguti, M. J., J.-D. Kim, et al. (2014). "An Overview of Kenyan Aquaculture: Current Status, Challenges, and Opportunities for Future Development." Fisheries and Aquatic Sciences 17(1): 1-11.

MUÑOZ, J. and F. PACIOS (2010). "GLOBAL BIODIVERSITY AND GEOGRAPHICAL DISTRIBUTION OF DIAPAUSING AQUATIC INVERTEBRATES: THE CASE OF THE COSMOPOLITAN BRINE SHRIMP, ARTEMIA (BRANCHIOPODA, ANOSTRACA)." Crustaceana 83(4): 465-480.

Munoz, J. 1., J. A. Green, et al. (2013). "Bird migratory flyways influence the phylogeography of the invasive brine shrimp Artemia franciscana in its native American range." Peer J 1(e200).

Mwanja, M., J. Rutaisire, et al. (2015). "Current fish hatchery practices in Uganda: The potential for future investment." International Journal of Fisheries and Aquatic Studies 2(4): 224-232.

Nasser, A. G. H., B. Peter, et al. (2009). "Morphometric and Preliminary Genetic Characteristics of Artemia Populations from Iran." Internat. Rev. Hydrobiol. 94(2): 194 - 207.

Nkambo, M., F. W. Bugenyi, et al. (2015). "Artemia Occurrence, Salinity and Ionic Rates in Saline Crater Lakes of Western Uganda." International journal of Ecosystems 5(2): 59-65.

Ogello, O. E., E. Kembenya, et al. (2014). "The occurrence of the brine shrimp, Artemia franciscana (Kellog 1906) in Kenya and the potential economic impact among Kenyan coastal communities." International Journal of Fisheries and Aquatic Studies 1(5): 151 - 156.

Papeschi., G. Alba, et al. (2008). "Heterochromatin variation in Artemia populations." Caryologia 61(1): 53 - 59.

Philips, P. R. (2010). "Recent Advances in fish hatchery management." Revista Brasileira de Zootecnia 39(101): $97-101$.

Radull, J., J. Rasowo, et al. (1992). "Effects of cultivation Techniques on the Characteristics of Cysts from a Salina in Kenya." Discovery and Innovation 4(1): 97-101.

Ramesh, R., K. Dube, et al. (2014). "Growth and survival of pengba, Osteobrama belangeri (Val.) larvae in response to co-feeding with live feed and microparticulate diet." Eco. Env. \& Cons. 20(4): 1715-1721.

Schwartz, S. H. (2008). Aquaculture Research Trends. New York, Nova Sceince Publishers, Inc.

Seenivasan, C., S. P. Bhavan, et al. (2012). "Enrichment of Artemia nauplii with Lactobacillus sporogenes for Enhancing the Survival, Growth and Levels of Biochemical Constituents in the Post-Larvae of the Freshwater Prawn Macrobrachium rosenbergii." Turkish Journal of Fisheries and Aquatic Sciences 12(23$31)$.

Sorgeloos, P., P. Dhert, et al. (2001). "Use of the brine shrimp, Artemia spp., in marine fish larviculture." Aquaculture 200: 147-159.

Sorgeloos, P., P. Lavens, et al. (1991). State of the art in Larviculture of fish and shell fish. Fish \& Crustacean Larviculture Symposium. P. Lavens, P. Sorgeloos, E. Jaspers and F. Ollevier. Gent, Belgium, European Aquaculture Society.

Sugumar, V. (2010). "Reproduction in the brine shrimp Artemia Leach, 1819 (Branchiopoda, Anostraca) from South India: Laboratory cross fertility tests and mating behaviour " North-Western Journal of Zoology 6(2): 162-171.

Tarekegn, A. A. (2015). Growth performance and survival rate of African catfish larvae Clarias gariepinus (Burchell 1822) fed on different types of live and formulated feeds. UNESCO-IHE Institute for Water Education. Delft, University of Natural Resources and Life Science (BOKU). Master of Science in Limnology and Wetland Management: 88.

Triantaphyllidis, V. G., J. T. Abatzopoulos, et al. (1996). "International Study On Artemia. LVI. Characterization of two Artemia populations from Namibia and Madagascar: cytogenetics, biometry, hatching characteristics and fatty acid profiles." Hydrobiologia 335: 97 - 106.

Triantaphyllidis, V. G., J. T. Abatzopoulos, et al. (1998). "Review of the biogeography of the genus Artemia (Crustacea, Anostraca)." Journal of Biogeography 25 213-226.

Triantaphyllidis, V. G., R. J. G. Criel, et al. (1997). "International study on Artemia. LIV. Morphological study of Artemia with emphasisto Old World strains. II. Parthenogenetic populations." Hydrobiologia 357(1997): 155163.

Triantaphyllidis, V. G., R. J. G. Criel, et al. (1997). "International Study on Artemia. LVII. Morphological and 
molecular characters suggest conspecificity of all Bisexual European and North African Artemia populations. ." Marine Biology 129(1997): 477-487.

Van Stappen, G., Ed. ( 2002 ). Zoogeography. In: Abatzopolous ThJ, Beardmore JA, Clegg JS and Sorgeloos P (eds.) Artemia Basic and Applied Biology. . Dordrecht/London/Boston. , Kluwer Acadamic Publishers

Vanhaecke, P., W. Tackaert, et al. (1987). "The Biology of Artemia: an updated review." Alternia Research and its Applications. 1987. Vol. 1. Morphology, Genetics, Strain characterization, Toxicology P. Sorgeloos, D. A. Bengtson, W. Decleir, and E. Jaspers (Eds). Universa Press, Wetteren, Belgium. 380 p. 